\title{
Research
}

\section{Social Role-Play Games Vs Individual Perceptions of Conservation and PES Agreements for Maintaining Rubber Agroforests in Jambi (Sumatra), Indonesia}

\author{
Grace B. Villamor $^{1}$ and Meine van Noordwijk ${ }^{2}$
}

\begin{abstract}
Financial incentives can both support and undermine social norms compatible with environmental service enhancement. External co-investment-e.g., through incentives from programs to reduce emissions from deforestation and degradation (REDD) and eco-certification-needs to synergize with local efforts by understanding local dynamics and conditions for free and prior informed consent. We assessed the perceptions and behavior of rubber agroforest farmers under existing conservation agreements as a step toward institutionalized reward schemes for agro-biodiversity using questionnaires and roleplaying games (RPG). To our knowledge, this is the first attempt to apply such a combination of methods to explore the perceptions of payments for environmental services (PES). Results revealed a strong conservation belief system and social norms in the research site, with indications that individual interest in converting old rubber agroforest to oil palm, with consequent private gain and loss of local social agrobiodiversity benefits, is suppressed in the social context of a role-playing game. In the game, all financial bids by external agents to secure an oil palm foothold in the village, were rejected despite indications of declining income in the village. Agents promoting an eco-certification scheme in the RPG had success and the responses obtained in the game can assist in the actual rollout of such a scheme without creating unrealistic expectations of its financial benefits. Co-investment schemes that require higher levels of trust and clarity of performance measures will have to address the potential discrepancy between individual preferences and community-level planning and decisions, while recognizing that social norms color the responses of individuals when presented with alternatives.
\end{abstract}

Key Words: conservation agreements; payments/rewards for agro-biodiversity conservation; role playing game; rubber agroforest

\section{INTRODUCTION}

Environmental services in the tropics are considerably diminished by the development and spread of land-use practices that profit the land user, but reduce the regularity and quality of water flows, habitat quality of the landscape for globally threatened biota, carbon storage capacity, and landscape beauty (Murdiyarso et al. 2002, Tomich et al. 2004). Although increased profitability may support development, the loss of environmental services affects the sustainability of overall resource use. Market-based instruments that make the continued provision of environmental services more profitable have become an active area of experimentation and learning over the past two decades (Engel et al. 2008), as purely regulatory approaches have a negative impact by perpetuating rural poverty. Market-based schemes to enhance environmental services in developing countries generally require monetizing biodiversity conservation, watershed protection, and carbon sequestration. Payment for environmental services (PES) schemes depend on funds derived from direct beneficiaries of such services, and/or an increased public interest in supporting conservation. These funds are used to offset legal opportunity costs of foregoing private benefits from activities with negative environmental effects (Peterson et al. 2010), and to provide additional income to land managers as a kind of poverty alleviation strategy, especially for poor areas in developing countries. Although most of the 
literature on PES focuses on design, possible arrangements, and clarification of what ecosystem services provide (Jack et al. 2008, Wunder 2008), few empirical studies so far have described the impact of PES on both land managers and the ecosystem service targeted. van Noordwijk and Leimona (2010) point out the need to assess the balance between perceived fairness and efficiency of existing schemes. The role of social motivation and persuasion as the third part of the "carrot, stick, and sermon" triangle (Bemelmans-Videc et al. 1998) is only gradually entering the debate on environmental and resource management (Sterner 2003, Vatn 2005). The interface of social motivation and monetization of environmental services is not trivial, and an economic ceteris paribus assumption that PES should enhance the supply of such services has been challenged by emerging experience in the context of rural development. Gómez-Baggethun et al. (2010) noted the growing body of literature (Vatn and Bromley 1994, Martinez-Alier 2002, Soma 2006, Kosoy et al. 2007, van Noordwijk et al. 2007, Child 2009) that raises the question of how the utilitarian framing of ecological concerns and market strategies can modify the way humans perceive and relate to nature, which in the long run may well prove to be counterproductive to conservation aims. Some of the first PES efforts in Southeast Asia are now reaching a point where these issues can be studied empirically (Leimona et al. 2008).

The behavioral economics literature includes experiments where the use of market norms can crowd out social norms and lead to non-monotonic relationships between level of payment and level of effort (Heyman and Ariely 2004). Ariely (2008) discusses cases where financial payment offered in a situation that is operated by social norms (e.g., high level of reciprocity and trust, collective action, and communal sharing) reduced motivation to engage, unless the payment was substantive. This is likely to happen in societies that depend solely on ecological life-support systems, particularly in regions in developing countries where market integration is only partial in many spheres. As argued by Leimona et al. (2009), the levels of PES cash transfers will remain small when expressed on a per capita level in Asian uplands, given the number of potential beneficiaries. Per capita payments so far have generally added less than $1 \%$, even compared with the low income levels of rural poor. Accordingly, introducing market norms into the equation may reduce the social norms that govern the management of resources. Gómez-Baggethun et al. (2010) documented the view that market-based mechanisms and economic incentives for conservation can induce the logic of individualism and competition in societies previously structured on the basis of community and reciprocity values. International organizations promoting market mechanisms should, therefore, be aware of potential undesirable outcomes and be cautious not to create market norms in places where such logic is inexistent or culturally discouraged by existing institutional structures.

Clark et al. (2011) built on the perspective of van Noordwijk et al. (2001) that natural resource management in the conflict-ridden uplands of rural Asia deals with multiple stakeholders and multiple knowledge systems, with asymmetric access to information and a contest at the level of knowledge and paradigms parallel with multiple perspectives on legality and de facto resource access. An important first step in negotiation support systems (NSS) to deal with this is to create a more shared understanding of the system properties and dynamics, and of the roles played by various stakeholders.

Role-playing games (RPGs) have emerged as tools for communication between villagers and researchers, as they put stakeholders as players in close-to-real situations (Barreteau et al. 2003, Dare and Barreteau 2003). They enable the testing of scenarios (e.g., social networks, various ecological patterns) and repetition with a high degree of control of chosen parameters. Barreteau et al. (2001) used RPGs for training, observation, and negotiation support, and as complements to the development and validation of multi-agent models (D'Aquino et al. 2003, Etienne 2003, Castella et al. 2005). In their companion modeling, Gurung et al. (2006) applied RPGs in the context of watershed management and conflict resolution to initiate and facilitate dialog between the villagers and the research teams. In their study, scenarios were simulated through RPGs. In the context of irrigated systems of the Senegal River valley, Dare and Barreteau (2003) investigated the link between role play and reality in a negotiation process. They found that the social background of the players influenced the role playing during the sessions. Their study suggests that, to understand social relationships among players, a combination of other tools such as sociological interviews and analysis of videos could be done together. 
This paper explores the degree of conservation awareness among villagers in conserving rubber agroforests and whether PES schemes in a nonmonetary form are sufficient to compensate nonconversion of agroforests into more profitable options. The case study refers to a context where strong social norms have so far maintained rubber agroforests as the primary livelihood strategy. Our specific questions were:

1. How are current conservation agreements perceived at the household level? Are household plans and ambitions aligned with village-level planning and commitments? Are differences between household strategies apparent?

2. What are the responses to land-use options in a social setting with competing agents who promote conversion and conservation? Do these social responses match individual preferences?

3. How can a role-playing game be used in the planning of further external coinvestment in environmental services, e.g., through forms of ecocertification?

\section{The Context: Conservation Agreements (CA)}

In Jambi Province, Indonesia, jungle rubber or rubber agroforest has been the dominant land use during the $20^{\text {th }}$ century (Joshi et al. 2003, Martini et al. 2010). Studies show that rubber agroforest is an important agro-ecosystem type that supports biodiversity conservation (Williams et al. 2001). Although rubber agroforest serves as a refuge for Red List and threatened species (Griffith 2000, Schroth et al. 2004, Rasnovi 2006, Beukema et al. 2007, Tata et al. 2008), it also provides ecosystem services such as soil conservation, protection of water quality, carbon sequestration, reduction of fire hazard, and landscape beauty (Joshi et al. 2003, Suyanto et al. 2005).

Despite positive ecological benefits of rubber agroforest, its latex productivity on an area basis is very low. Joshi et al. (2006) calculated the yield of rubber agroforest, which is $400-600 \mathrm{~kg}$ of dry rubber compared with rubber monoculture, which is $1000-1800 \mathrm{~kg}$ per ha per year. However, farmers benefit from other resources of the rubber agroforest such as food, fruit (e.g., durian, mangosteen, coffee, etc.), fodder, fuel wood, and timber (Gouyon et al. 1993, Michon 2005).

In the last decade of the 20th century, the combination of improved road access, an inflow of migrants, and the emerging oil palm industry put pressure on the remaining forest (Fig. 1) (Ekadinata et al. 2010). As documented in detail by Miyamoto (2006a, 2006b, 2007), the increase in land-use intensity may have actually anticipated the increased availability of labor that would make large rubber areas profitable through share-tapping arrangements. The transition from rubber agroforest (with a time-averaged aboveground carbon stock of 70-80 Mg ha ${ }^{-1}$, depending on the management regime) to continuous/permanent cropping such as monoculture of oil palm and rubber (both with a time-averaged aboveground carbon stock of about $40 \mathrm{Mg} \mathrm{ha}^{-1}$ ) led to increased carbon emissions (van Noordwijk et al. 2008).

Efforts to retain existing rubber agroforests are relevant for the ongoing implementation of REDD strategies in Jambi Province (Akiefnawati et al. 2010). The potential public value of maintaining rubber agroforest for its biodiversity is probably more relevant than the impacts on carbon emissions because it coincides with local value as the agroforest area around a village is still seen as a "club good" (Paavola and Adger 2005) with access to most non-rubber products for all community members.

The development of a reward scheme for biodiversity conservation was supported through action research under the Rewarding Upland Poor for Environmental Services (RUPES) Phase 1 project operated since 2002 by the World Agroforestry Centre (ICRAF). The target of the action research was to identify the ecosystem services, explore how they could be measured, to whom rewards should go, who might be willing to pay for rewards, how and in what form funds could be collected, and what amount or form would be appropriate. To obtain answers to these questions, the action research follows a conceptual framework considered appropriate for developing pro-poor PES schemes shown in Fig. 2.

One of the early outputs of this project was the establishment of conservation agreements (CAs) as an initial step in the institutionalization of reward 
Fig. 1. Land-cover change between 2002 and 2008 in Jambi Province (Source: Ekadinata et al. 2010)

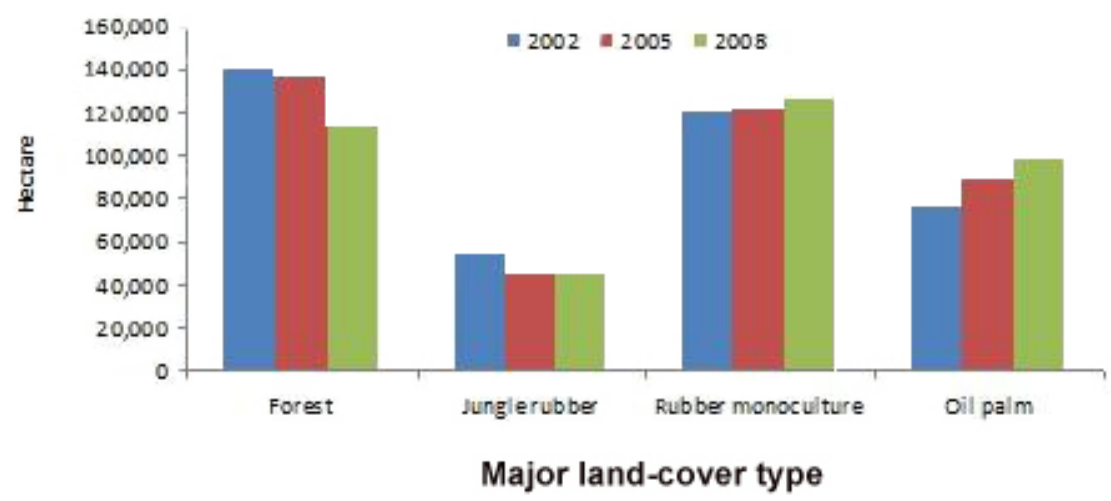

schemes for agro-biodiversity. Four CAs on agrobiodiversity conservation (the result of a long process of discussion and exploration with local villagers in the area) appropriate for rubber agroforests were created and signed in 2007 by the villagers (Table 1). It should be noted that none of these schemes provided direct monetary payments to the villagers.

Together with the agreements, support funding was provided by the RUPES Program to the communities as a part of the RUPES goals to preserve the biodiversity-rich rubber agroforests combined with the economic needs. Through the village heads with assistance of a local NGO (e.g., WARSI-WARung konservaSI (or Indonesian Conservation Community)), the communities received and managed the support funds. The agreements included the farmers' rubber agroforest practices, management plan, and monitoring activities.

Based on the communities' performance, it is hoped the villages will negotiate and build their case for rubber latex ecocertification (or eco-labeling) and REDD schemes. These market-based incentive schemes are perceived to be the only way to save the remnants of forests and rubber agroforests from being converted to rubber monoculture and oil palm plantations (Feintrenie and Levang 2009).

\section{METHODS}

\section{Site Description}

The study site is located in Bungo district, Jambi province, (Sumatra) Indonesia (see Fig 3). Within the district, three adjacent villages under the Bathin III Ulu sub-district were selected, namely: Lubuk Beringin, Laman Panjang, and Desa Buat. The villages are near the foothills of Kerinci Seblat National Park. Except for Desa Buat, these villages are considered poor and have poor access to market roads and electricity infrastructures due to their distance from the district center (i.e., 2-hr drive by motorbike). The population status of the three main villages is presented in Table 2 . Their main source of food is rice; and the main source of income is rubber (Hevea brasiliensis) and occasionally durian and other local fruit and medicinal plants obtained from the rubber agroforests.

The majority of the population belongs to two ethnic groups namely, Jambi and Minang. They follow the traditional practice of a joint-family or lineage ownership of land wherein a matrilineal inheritance system is applied to paddy fields and a patrilineal inheritance system to rubber fields (Suyanto et al. 2005). Each village has appointed village heads and community rules (i.e., Peraturan dusun or PERDUS) in managing their village forests (Akiefnawati et al. 2010, Martini et al. 2010). The people in these villages have strong ties with each other and very much respect their village elders. 
Fig. 2. Conceptual framework for establishing a pro-poor rewards scheme for agro-biodiversity conservation.

\begin{tabular}{|c|c|c|}
\hline $\begin{array}{l}\text { Context } \\
\text { - Realistic: } \\
\text { Assessment of impacts } \\
\text { of land-use change on } \\
\text { change of } \\
\text { environmental services } \\
\text { - Pro-poor: } \\
\text { Assessment of multiple } \\
\text { dimensions of poverty }\end{array}$ & $\begin{array}{l}\text { Mechanism } \\
\text { - Conditional: } \\
\text { Performance-based } \\
\text { contracts } \\
\text { - Voluntary: } \\
\text { Process of negotiations }\end{array}$ & $\begin{array}{l}\text { Outcome \& Impact } \\
\text { - } \quad \text { Per capita financial } \\
\text { transfers remain small but } \\
\text { with tenure security } \\
\text { - } \quad \text { Reduced conflict over } \\
\text { resource access (more } \\
\text { options); less poverty } \\
\text { Coinvestment in } \\
\text { stewardship rather than } \\
\text { PES }\end{array}$ \\
\hline
\end{tabular}

\section{Survey Questionnaire}

A survey was conducted to explore local farmers' perspective of the CAs. A total of 100 household respondents (93 males and seven female heads of the household) were randomly selected from the three villages. Under the RUPES program, Desa Buat and Laman Panjang Besar villages do not participate in CAs. Each selected respondent was interviewed about the following facets: (1) awareness of the CAs; (2) motivation to participate and continue; (3) perspective on the agreements regarding their potential to conserve biodiversity in the area; and (4) future land-use preferences. A descriptive statistical analysis was used to analyze the data (Table 4). Interviews were mostly conducted with household heads because they are closely involved in and had a good knowledge of rubber farming. Secondary information was collected and reviewed, and key informant interviews with RUPES researchers, village heads, and store vendors (mostly women) were also conducted for triangulation. The survey and interviews were conducted between February and March 2010.

\section{Role-Playing Game}

The RUPES RPG was designed for the inauguration of a RUPES training course in Chiang Mai in 2003 and was used, among other things, at the 2006 international RUPES Conference in Lombok. The rules and settings of this RUPES game were originally based on a typical village in the rubber agroforest landscape of Jambi, similar to Lubuk Beringin. The game was simplified and modified for this research, adding the concept of ecocertification for higher pricing of latex from rubber agroforest as a reward scheme. Below are details of materials, agents and their roles, and game settings and session.

\section{Game board}

Three land-use game boards with $5 \times 5$ grids (with dimension of $5 \times 5 \mathrm{~cm}^{2}$ per grid) marked with different land-cover types were prepared (Fig. 4). Each sub-watershed (or game board) has one village $(\mathrm{V})$, one unit of paddy field (R), nine units of rubber agroforest plots (RAF), and 14 units of forest $(\mathrm{F})$.

\section{Agents and their roles}

There are six types of players, each with the following roles and descriptions:

1. Villagers: The villagers' target is to maintain a minimum of 1 Rupee per year for each person living in the village to sustain themselves, beyond what the rice fields yield. To increase their standard of living, they have to raise additional income; the name of the currency and its value has only a vague 
Table 1. Conservation agreement schemes for rubber agroforest conservation

\begin{tabular}{|c|c|c|}
\hline Schemes & Ecosystem services type ${ }^{\dagger}$ & Target benefits for the community \\
\hline $\begin{array}{l}\text { (1) Provision of high-yielding, grafted } \\
\text { (clonal), rubber seedlings }\end{array}$ & - provisioning services & $\begin{array}{l}\text { To increase the latex yield production of } \\
\text { jungle rubber by mixing with grafted } \\
\text { (clonal) planting material }\end{array}$ \\
\hline $\begin{array}{l}\text { (2) Establishment or revival of } \\
\text { communal jungle rubber areas (with } \\
\text { specific work plans) }\end{array}$ & $\begin{array}{l}\text { - supporting services } \\
\text { - regulating services }\end{array}$ & $\begin{array}{l}\text { To conserve the agro-biodiversity in the } \\
\text { area by maintaining jungle rubber areas; } \\
\text { and } \\
\text { To use as a pilot test for village forest } \\
\text { rights }\end{array}$ \\
\hline $\begin{array}{l}\text { (3) Installation of micro-hydro power } \\
\text { plants along the river }\end{array}$ & - provisioning services & $\begin{array}{l}\text { To provide electricity to the villagers and } \\
\text { to regulate and maintain the river flows }\end{array}$ \\
\hline $\begin{array}{l}\text { (4) Establishment of mini-reservoirs } \\
\text { along the riversides }\end{array}$ & - provisioning services & $\begin{array}{l}\text { To maintain fish stocks for food } \\
\text { consumption }\end{array}$ \\
\hline
\end{tabular}

${ }^{\dagger}$ Following the basic categories from the Millennium Ecosystem Assessment

${ }^{\ddagger}$ For information about tenure security of rubber plots see Suyanto et al. (2005)

relationship with reality (where at least a million Indonesian Rupiah per household member would be needed to achieve such goal). Within the game, the villagers make decisions jointly on land use, and jointly respond to the various proposals and bids made by "external agents" visiting their village.

2. Buyer 1: A logging company agent for pulp wood and paper who wants to make a deal with the villagers to convert natural to logged forest and who is offering an attractive price. The buyer's target is to convert all the units of the forest to logging areas;

3. Buyer 2: An oil palm company agent who promises to convert any type of land to oil palm that will give a negotiable net benefit in the third year after conversion. The buyer's target is to convert at least 40 units of land in the catchment, otherwise the company will go bankrupt;

4. A "Save the Tiger" (NGO) agent who offers negotiable rewards to villages who still have at least 10 plots of continuous forest cover. A minimum of 40 units of intact forest must be maintained at all times within the watershed to prevent local extinction. Once the village meets the NGO's target, a certificate of conservation effort (sticker) will be awarded;

5. A watershed protection board officer who offers some rewards for intact forest. The officer's target is that all villages in the valley make a clear commitment to protect the water resource. Once the village meets the board's target, a certificate of conservation effort will be awarded; and

6. Buyer 3: A "green rubber" company representative looking for sustainable rubber production. The company's goal is to support the village with rubber agroforest farms where they will have a watershed protection program and will also support tiger conservation. Once the village meets the board's target, a certificate of conservation effort will be awarded.

\section{Settings}

On the game board, each land unit provides the following income (rupee) per year: paddy fields = 10 rupee; rubber agroforest $=4$ rupee; forest $=1$ 
Fig. 3. Map of the study site (Bungo district), Jambi Province, Indonesia.

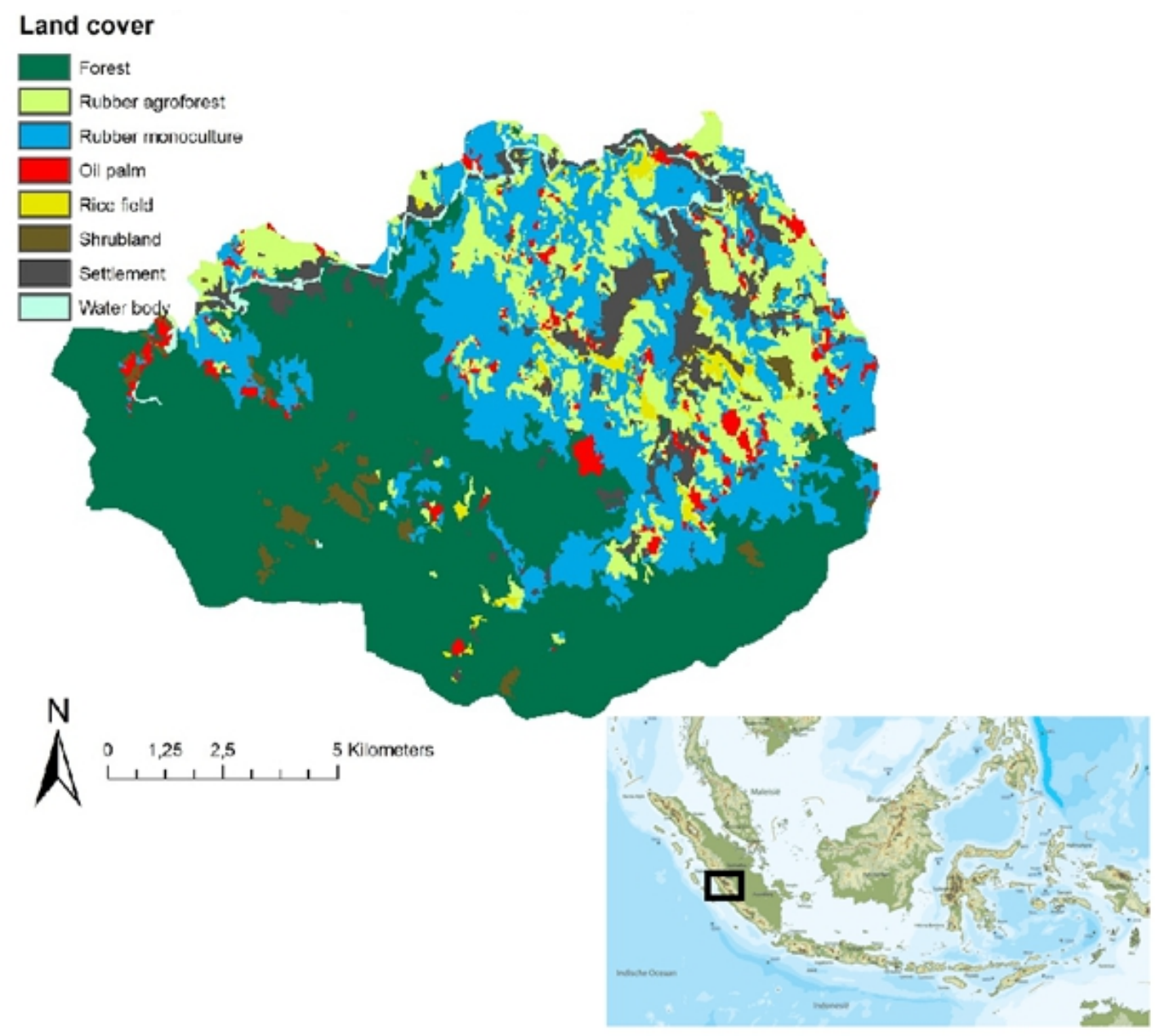

rupee; logged forest $=$ negotiable payment $(0$ rupee per year thereafter); village $=15$ rupee; oil palm plantation $=8$ rupee (but no cash income during the first 3 years); and sustainable green rubber $=2$ rupee.

Due to the physical constraints of their land, the villagers could not expand their paddy fields and village area. The population at year zero is 75 . A score sheet is provided to track the scores on how targets are met, and to monitor the financial conditions (Table 3). Play money was used for the buyers (i.e., oil palm company, logging concession company, watershed protection board, "Save the Tiger" NGO, and green rubber company) and stickers were used to recognize the village conservation efforts.

\section{Game session}

The game was carried out in March 2010. For the game, the same farmers were invited who had been individually interviewed in their "real world" context. Volunteers among them were asked to play one of the "external agent" roles, and the others formed a collective of seven farmers managing a village. Not all interviewees were able to participate, but those who did included both farmers with and without formal roles in the village organizations. Most were men. And the composition of each group was deemed broadly representative of each village.

After roles were voluntarily selected, instructions were provided on how to play the game. The group 
Table 2. Population and number of households in the study site (Source: 2003 Statistics of Rantau Pandan Sub-District)

\begin{tabular}{|c|c|c|c|c|c|c|}
\hline \multirow[t]{2}{*}{ Village } & \multicolumn{3}{|c|}{ Population } & \multirow[t]{2}{*}{$\begin{array}{l}\text { No. of persons } \\
\text { per } \mathrm{km}^{2}\end{array}$} & \multirow[t]{2}{*}{$\begin{array}{c}\text { No. of } \\
\text { households }\end{array}$} & \multirow[t]{2}{*}{$\begin{array}{c}\text { Average no. of } \\
\text { persons/ } \\
\text { household }\end{array}$} \\
\hline & Male & Female & Total & & & \\
\hline a. Lubuk Beringin & 184 & 212 & 396 & 27.22 & 102 & 4.02 \\
\hline b. Laman Panjang & 366 & 365 & 731 & 41.17 & 182 & 4.04 \\
\hline c. Buat & 566 & 514 & 1080 & 93.28 & 267 & 4.25 \\
\hline Total & 1116 & 1091 & 2207 & & 551 & \\
\hline
\end{tabular}

of buyers received their instructions separately from the villagers. Not explicitly knowing each other's role description beyond what agents disclosed in discussions, was considered part of the game design. Conflicting and contradictory roles were left to find innovative solutions within the games' context. In every time step or round, the buyers visited the villages and negotiated for their respective targets. Each round of negotiation was about 15 minutes. The game master announced when the time was over and the buyers went back to their respective places to check their targets. At the same time, the villagers calculated their income for the given year using the score sheet.

Once the basic routines of the game were understood, additional exogenous changes were announced as scenarios or stressors in the game, complicating the players' attempts to meet their targets. In round 3, a transmigration program was enforced where the population increased by $20 \%$. In year 4, three units of forest were burned down in a natural forest fire, and in year 5, the rubber price was decreased by $50 \%$.

The whole game was facilitated by a game master who oversaw and checked that all the rules were complied with and by four assistants helped the players and recorded the interactions. The game was announced to have indeterminate length, but after a total of six rounds had been played, the game was ended and jointly evaluated. All external agents and villagers were asked to tell and explain what they did, helped by questions from the external observers of the game.

\section{RESULTS}

The descriptive statistics of the key socioeconomic variables and CA perceptions from the survey show that the majority of the respondents are rubberbased farmers with $52 \%$ of their income from rubber-latex production with an average landholding of 7 ha (Tables 4 and 5). The villagers' ages range from 23 to 75 years.

\section{Participation and Motivation}

Of the 100 household respondents interviewed, $75 \%$ participated in CAs (Table 5). The most preferred scheme is the mini-hydro power plants, which generate electricity for the village members during nighttime (Fig. 5). This is one of the main motivations for villagers continuing with the CA. The villagers, especially in Lubuk Beringin, viewed the mini hydro-power plant as a way to protect the river, the forest, and the rubber agroforest (Lubuk Beringin village head, pers. comm.). The majority of the respondents availed themselves of a combination of two to four schemes, e.g., a combination of grafted (clonal) rubber seedlings, mini hydro-power, and communal rubber agroforest farms. For example, in Lubuk Beringin, 2 ha of 
Fig. 4. Land-use game board with units of forest (F) and rubber agroforest (RAF), a unit of paddy field $(\mathrm{R})$, and village settlement (V).

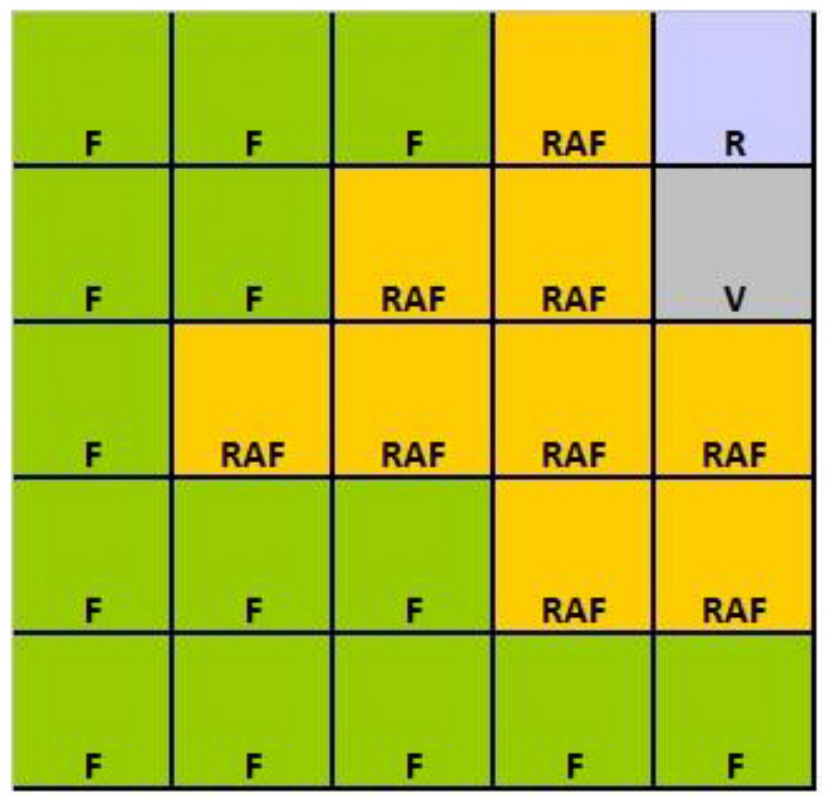

communal rubber agroforest farms were established, and two mini hydro-power plants were installed. In Sungai Letung (a sub-village of Buat), 3 ha of communal rubber agroforest farms were established. In Sangi (a sub-village of Buat), grafted (clonal) rubber seedlings were provided to plant alongside the old rubber trees. Three rubber farmer groups and nurseries were established and two micro-hydro power plants were installed in Laman Panjang.

About $25 \%$ of the respondents were not involved in pre-existing CAs either because they had not been informed about the RUPES project (and previous ICRAF project) or because they were not part of the RUPES project assistance due to their distance from the target villages. Based on the information from these respondents, the perceptions on their future land-use preferences could be compared with those of the respondents involved in CAs.

Around 60 of the respondents signified their intention to continue with the contract, but 15 wanted to discontinue (Table 5). The reason for not continuing is due to the poor performance of grafted (clonal) rubber seedlings (e.g., many of the grafted seedlings did not survive), the fear of limiting lands for crop expansion, and low confidence in their village heads.

\section{Potential of Conservation Agreement Schemes to Conserve Biodiversity}

The main reason for the development of the CA schemes in Jambi is the aim to preserve the remaining rubber agroforest because of the substantial ecosystem services it provides. The survey results reveal that $66 \%$ of the respondents agreed, but $19 \%$ disagreed and $15 \%$ had no preference.

\section{Preferred Land Use}

If provided with additional financial investments, for example, establishment of credit facilities, $43 \%$ of the respondents preferred to remain engaged in rubber agroforests, $18 \%$ preferred monoculture rubber, and $20 \%$ expressed interest in oil palm plantation. Further reasons for their land-use 
Table 3. Sample score sheet for each village group

\begin{tabular}{|c|c|c|c|c|c|c|c|c|c|c|c|c|c|}
\hline \multirow[t]{2}{*}{ Land-use type } & \multirow{2}{*}{$\begin{array}{l}\text { Income per } \\
\text { year }\end{array}$} & \multicolumn{6}{|c|}{ Number of plots/units ${ }^{\dagger}$} & \multicolumn{6}{|c|}{ Income } \\
\hline & & Y0 & $\mathrm{Y} 1$ & $\mathrm{Y} 2$ & Y3 & Y4 & Y5 & Y0 & Y1 & $\mathrm{Y} 2$ & Y3 & Y4 & $\mathrm{Y} 5$ \\
\hline Forest & 1 & 14 & 14 & 14 & 14 & 11 & 11 & 14 & 14 & 14 & 14 & 11 & 11 \\
\hline Logged forest & 0 & 0 & 0 & 0 & 0 & 0 & 0 & 0 & 0 & 0 & 0 & 0 & 0 \\
\hline Agroforest & 4 & 9 & 9 & 9 & 9 & 9 & 9 & 36 & 24 & 20 & 20 & 20 & 10 \\
\hline Ricefield & 10 & 1 & 1 & 1 & 1 & 1 & 1 & 10 & 10 & 10 & 10 & 10 & 10 \\
\hline Village & 15 & 1 & 1 & 1 & 1 & 1 & 1 & 15 & 15 & 15 & 15 & 15 & 15 \\
\hline Total & & 25 & 25 & 25 & 25 & 22 & 22 & 75 & 83 & 67 & 65 & 62 & 55 \\
\hline Required & & & & & & & & 75 & 75 & 75 & 90 & 90 & 90 \\
\hline No. of stickers & & & & & & & & & 7 & 8 & 6 & - & 10 \\
\hline
\end{tabular}

$\dagger$ Each plot refers to a grid cell of the game board.

Income per land-use type per year is multiplied to each corresponding number of plots at each time step.

choices were explored (Table 6). For conservation of agro-biodiversity, the rubber agroforest is still the top land-use choice (Fig. 6).

\section{Social Behavior in RPG}

The RPG tested what might be the possible reactions of the villagers if buyers were interested in converting their rubber agroforests or maintaining them through PES schemes.

First of all, all villages in the game designed their simulated landscape (game boards) according to the actual village land-use configuration. They based the arrangement according to the land use that is immediately adjacent to their villages. For example, the village (settlement area) should be immediately connected to the paddy field and the paddy field should be surrounded by rubber agroforest.

The game lasted for more than $3 \mathrm{hr}$, with six rounds or time steps (each time step was supposed to represent 1 yr) (Fig. 7). Throughout the whole game, the land-cover types and their arrangement did not change. Scenarios or stressors, e.g., population increase, forest fire, and rubber price drop, were simulated to see if villagers would be interested in selling their units of forests and agroforests for more profitable ventures, e.g., oil palm plantation and logging concession. None of the villagers took the attractive offers.

The performance of the villages was assessed based on the results of their yearly income (Table 7). The required income should match the village population needs, i.e., to maintain a minimum of 1 rupee per year for each person living in the village. However, if the villagers want to increase their standard of living, they have to raise additional income. During year 0 and year 1 , three villages were able to meet the required target of 75; Laman Panjang even exceeded its target in year 1 . Then, in year 2, Lubuk Beringin performed very well, Desa Buat met the target, but Laman Panjang was 8 points short. When population increase, forest fire, and rubber price drop were imposed in years 3,4 , and 
Table 4. Descriptive statistics of the respondents in the study site for 2010

\begin{tabular}{lllll}
\hline \hline Variables & Mean & Std. deviation & $X_{\min }$ & $X_{\max }$ \\
\hline Age & 45.0 & \pm 12.6 & 23 & 75 \\
Ethnicity & 2.6 & \pm 0.9 & 1 & 4 \\
Household size & 4.7 & \pm 1.6 & 2 & 9 \\
Education level & 1.1 & \pm 0.62 & 0 & 2 \\
Labor availability & 3.4 & \pm 1.6 & 1.6 & 8 \\
Land holdings (ha) & 7.0 & \pm 14.6 & 1 & 142 \\
Gross annual income $(\$)^{\dagger}$ & 4,907 & \pm 696.2 & 120 & 45,428 \\
Gross annual income per capita $(\$)^{\dagger}$ & 1,176 & \pm 2006.1 & 30 & 11,918 \\
\% income from rubber latex & 52.2 & \pm 42.9 & 0 & 100 \\
\% income from rice production & 13.3 & \pm 25.2 & 0 & 100 \\
\% income from non-timber forest products & 4 & \pm 1.3 & 0 & 100 \\
\% income from other sources & 20.5 & \pm 3.4 & 0 & 100 \\
& & & & \\
\hline
\end{tabular}

$\dagger \operatorname{US} \$=9,000.00$ rupiah (at the time of writing)

5, respectively, incomes plummeted despite the attractive financial offers from oil palm and logging companies. In year 4, only Lubuk Beringin was able to meet the target income but hardly recovered after another year. This suggests that villagers preferred to maintain the original land cover and were satisfied with the minimal incentives provided by the watershed protection board and the "Save the Tiger" NGO. Most of the villagers earned income from maintaining units of agroforest and forests, thus the "green rubber" company paid additional income. However, the concept of eco-labeling was not explicitly described to the villagers during the game.

\section{DISCUSSION}

\section{How Are Current Conservation Agreements Perceived at the Household Level? Are Household Plans and Ambitions Aligned with Village-Level Planning and Commitments? Are Differences between Household Strategies Apparent?}

Although none of the schemes from the CAs were providing direct monetary payments at the time of the survey, the CAs set the stage for potential ways of pursuing ecocertification as well as REDD schemes. Ecocertification, or labeling, of rubber latex from rubber agroforest and the REDD scheme are ways to increase the income of the rubber agroforest farmers for the agro-biodiversity services they provide. The combination of RPG and survey results reveals strong support from village farmers for conservation of rubber agroforests. 
Table 5. Descriptive statistics of the respondents on conservation agreements for 2010

\begin{tabular}{llllll}
\hline \hline Key Variables & $\mathrm{N}$ & Range & Mean & Std. Deviation & $\begin{array}{c}\text { Frequency/\# of } \\
\text { individuals }\end{array}$ \\
\hline
\end{tabular}

\section{Participation in CA}

a) No answer

b) Yes

c) No

II. Type of CA schemes joined
a) Clonal material
b) Communal jungle rubber
c) Mini-hydro
d) Fish conservation

III. Willingness to continue or participate
a) No answer
b) Yes
c) No

IV. Conservation agreement is enough to maintain the rubber agroforests
a) No answer
b) Yes
c) No
V. Preferred land use for financial reasons
a) No answer
b) Rubber agroforest
c) Monoculture rubber
d) Oil palm plantation
e) Others (e.g., rice)

VI. Preferred land use for agro-biodiversity conservation
a) No answer
b) Rubber agroforest
c) Forest
d) fallow areas
e) Other
f) Not sure

100

2

2

1.2

$1.2 \pm 0.46$

3
75
22

100

4

2.3

$\pm 0.18$

45
45
4

34

100

2

1.10

$\pm 0.62$

(10)

15
60
60

60
25

100

2

1.04

$\pm 0.60$

100

5

1.62

$\pm 1.15$

15

66

19

$1.62 \pm 1.15$

100

6

1.33

$\pm 1.10$
Rewards for conservation of agro-biodiversity are not always in monetary form. The example of the Jambi case shows that rewards could be of direct importance to the villagers' needs such as electricity and access rights, e.g., communal rubber agroforest farms. As the area is far from the district center, access to public services such as electricity is lacking. Hence, the establishment of mini-hydro power plants even indirectly to conserve the rubber agroforests was seen as a success and motivated the villagers to continue the CAs. As the rubber agroforests of the villages border on and are partly classified as watershed protection forest, the key issues for the villages were their lack of tenure 
Fig. 5. Preferred conservation agreement (CA) schemes, 2010 in Jambi Province.

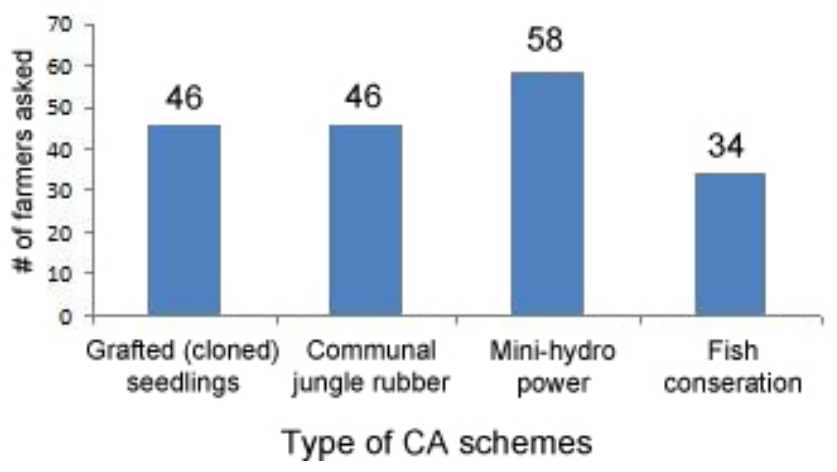

security and authority to deal with external disturbance to the forest upstream. van Noordwijk et al. (2008) found that planting trees brought communal land under private control, and a small number of tappable rubber trees per hectare was enough to establish a claim. Thus, the emphasis was on extensive rubber gardens, where the local rules in many villages follow the "fallow rotation reserves" (locally called sesap-nenek or ancestors' bush; Martini et al. 2010). Thus, the RUPES program provided technical assistance for establishing communal rubber agroforest farms in harmony with the villages' local custom and the community-based forest management (Akiefnawati et al. 2010).

The poor performance of grafted clonal rubber seedlings was seen as the only unsuccessful scheme for some farmers, but this was negligible compared with the success of bringing electricity to the remote areas through the mini-hydro plants. Farmers under this scheme complained that the planting material did not survive or did not produce the expected yield. We did not ask further details about the perceived probable causes for non-survival of those clones.

In conclusion, the villagers expressed interest in what the RUPES activities have achieved so far, but $20 \%$ of farmers interviewed expect that, in 10 years' time, monoculture oil palm will have replaced part of the current rubber agroforests.

\section{What Are the Responses to Land-Use Options in a Social Setting with Competing Agents Who Promote Conversion and Conservation? Do these Social Responses Match Individual Preferences?}

Before the implementation of CAs, most of the farmers in the area were strongly considering switching to monoculture systems if investments were to be provided (Bennett 2009, Leimona and Joshi 2010). This corresponds with the results of the preferred land use (Table 4). If provided with financial credits for upfront investment, there is a good chance that some of these farmers will shift to a monoculture plantation crop. Interestingly, the farmers' interest in oil palm and rubber monoculture did not emerge during the RPG.

Regarding the social behavior of farmers and villagers toward the buyers and agents, the following were observed:

- The villagers were very reluctant to negotiate with oil palm and logging companies despite the attractive profits. This might be due to their strong belief system in conservation, which could be attributed to their long experience with various conservation and research organizations. For example, the RUPES project has been in the area since 2002, whereas the Integrated Conservation and Development Project (ICDP) started in 1998 (Akiefnawati et al. 2010). Accordingly, during the ICDP days, Lubuk Beringin was already involved in an agreement that includes maintaining forest areas, not 
Table 6. Reasons for the land-use choice of the respondents in the study site, 2010

\begin{tabular}{|c|c|c|}
\hline Jungle rubber/rubber-mixed agroforest & Oil Palm Plantation & Intensive rubber cultivation \\
\hline Easy to manage & Short farming period & Higher yield production \\
\hline $\begin{array}{l}\text { Produce various crops (e.g. fruits and medicinal plants } \\
\text { at the same) time }\end{array}$ & $\begin{array}{l}\text { Highly-priced } \\
\text { commodity }\end{array}$ & $\begin{array}{l}\text { Short tree spacing (thus higher tree } \\
\text { density per farm plot) }\end{array}$ \\
\hline \multicolumn{3}{|l|}{ Well-established farming experience } \\
\hline \multicolumn{3}{|l|}{ Lower labor requirement } \\
\hline Higher resistance against pest and diseases & & \\
\hline
\end{tabular}

opening lands with slopes of more than $30^{\circ}$, and planting bamboo along riversides. Hence, some of these farmers must have shared their conservation vision during the game. The game was conducted in the presence of two researchers who were also involved in the RUPES project in the area, but we are unsure whether this influenced the behavior of the players. This tool was implemented for the very first time in the study area. The survey and interviews, as suggested by some studies (Dare and Barreteau 2003), helped to verify and check farmers' behavior during the game.

- Synergy between the two economic agents, oil palm and logging concession companies, together with stressors did not help to convince the farmers to take their offers, suggesting strong non-economic motivations of the villagers. In reality, most of the rubber agroforest farmers who would like to engage in oil palm or monoculture rubber suffer from financial and labor constraints. They mostly depend on their family labor. The mean available labor and landholdings per household are not enough for labor-intensive farming practices such as oil palm or rubber monoculture plantation (Table 3 ).

- Those who dominate negotiation in the villages, i.e., village elders, have the final say on how to use the land. Although, on some occasions, other members were already interested in engaging with oil palm and logging companies, the final decision came from the eldest member of the group, particularly the one with a community leadership position. In reality, most of the villagers belong to the Jambi ethnic group, which has great respect for community elders. Young members of the village have a high regard for the village elders and heads because of their strong adherence to patrilineal and matrilineal traditions.

In a recent application of RPGs in the Colombian Amazons, Vieira Pak and Castillo Brieva (2010) were able to extract relevant information about decision rules for the multi-agent model. Accordingly, individual and collective decisions were identified, including specific decisions not common to the group, which influenced the landcover transformation.

In conclusion, at least some of the responses obtained in the RPG setting contrast with opinions on individual preferences expressed in individual survey interviews. Without claiming either of these types of evidence to be true or false, this points to the importance of "social control" and social norms in the local context, constraining the behavior and choices of individual households.

\section{How Can a Role-Playing Game Be Used in the Planning of Further External Coinvestment in Environmental Services, e.g., through Forms of Ecocertification?}

In this research, an RPG was set up in the context of social learning for all engaged, and not as a classical "extractive" research tool aimed at 
Fig. 6. Preferred land use to support agro-biodiversity conservation, 2010 in Jambi Province.

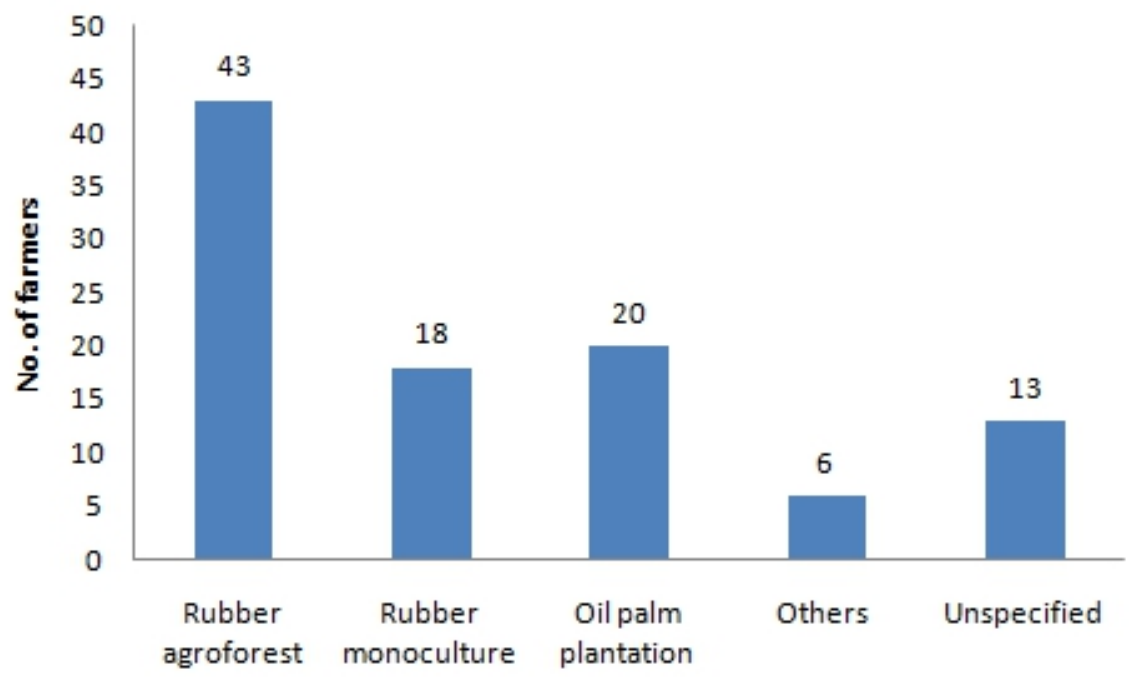

maximizing gains for the researcher at the cost of learning by participants. The choices made in designing and implementing the game reflect this goal. For example, an alternative choice could have been to have villagers only play their "own" role in the game and have real external agents represent the various other roles. This might be one step closer to a simulation of reality, but would add other elements where the players would not know each other beforehand, and would make it more difficult to gauge the roles as such.

In the final round of evaluation of what happened in the game, the villagers expressed that they found the game very interesting and that it helped them to see how their villages faced economic difficulties, especially after the round in which exogenous stressors were imposed. They found the game easy to grasp because the rules and settings were created based on their actual village conditions. Also, they were able to communicate with each other and their neighboring villages. This helped to simulate a natural and realistic social environment.

Beyond such learning for the local stakeholders, the game also provides insights for intermediaries considering further types of modalities for supporting environmental services provisioning in the villages. This does not mean that the researchers should take the experience in the game as a reflection of any absolute truths that are independent of the way the information was collected. As in virtually any social science research, the observer influences what is being observed, and respondents may provide "politically correct" responses to please the outsider. According to Jager et al. (2002) (field) experiments, particularly those capturing social behavior, provide data of limited absolute validity because they are based on limited (quasi-) experimental variations applicable during relatively short time periods. Thus, we could say that the social behavior observed during the game reflects what might happen in such a period of time and under the conditions or game settings, but does not allow inferences beyond such scales and conditions.

So far, we have only one replication of the game in this village setting, and details of what transpired may be linked to the specific interpretation of the roles in this case. Many of the results of playing the game with villagers were, however, consistent with those from about ten other occasions where modifications of the game were played with intermediaries interested in the development of PES schemes in practice. However, the relative success of logging and oil palm agents was smaller than in any previous implementation of the game with participants who mostly hold university degrees, whereas the effectiveness of the ecosystem servicesenhancing agents was remarkably high. 
Fig. 7. Village groups discussing their decisions with their game boards. (Photos by G.Villamor.)
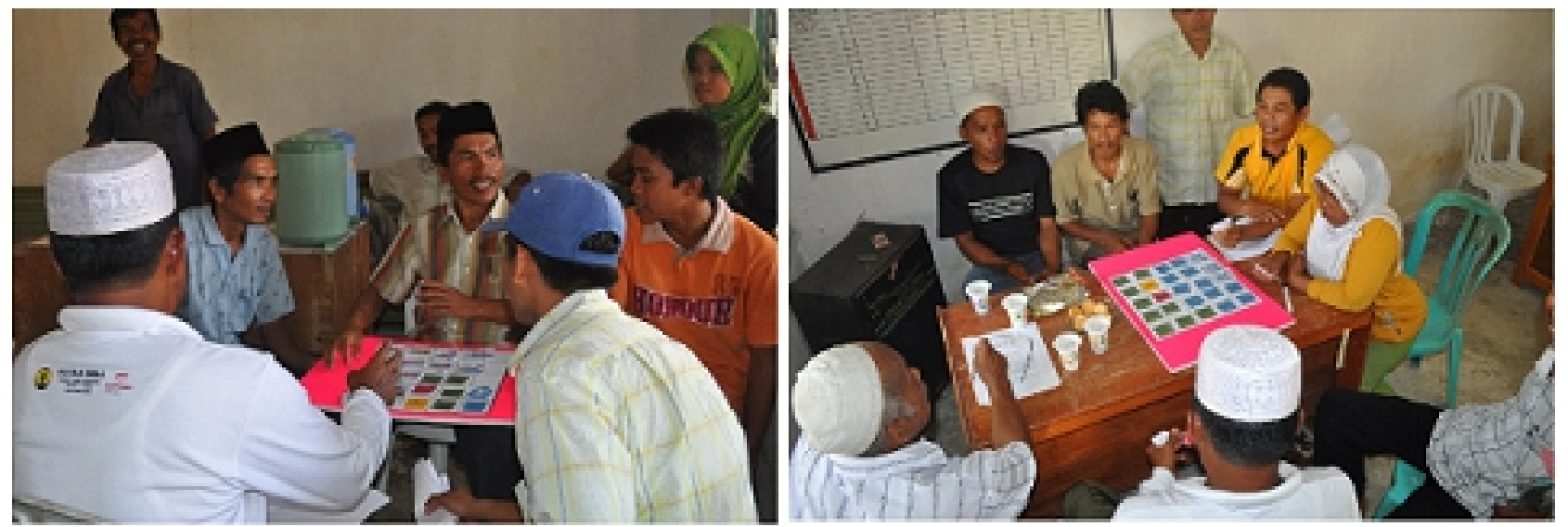

Despite the lower profits offered, the watershed protection board, the "Save the Tiger" NGO, and the green rubber company were the most successful agents in the game when played in the village context. The number of certificates awarded by these agents to the villagers for maintaining units of forest and agroforests were seen as recognition. Heyman and Ariely (2004) perceived a social market condition when there is no monetary reward. This might reflect an example of social norms operating among the villagers, far beyond what a more critical and formally educated audience would expect to be "real."

The concept of PES on ecocertification and REDD was implicitly introduced using the concept of "sustainable green rubber" in which rewards can only be received if the conditions, such as complying with the rules of the watershed protection board and the "Save the Tiger" program, were met. In reality, the recent REDD+ policy and proposed ecocertification schemes set conditions and criteria for forest protection and biodiversity conservation. The concept of hutan desa (village forest) in Indonesia was first implemented in Lubuk Beringin where 2300 ha of forests were set aside for a proposed REDD scheme (Akiefnawati et al. 2010).

Conservation agreements as initial pilot tests on how to pursue larger reward schemes, e.g., ecocertification and REDD, could provide credible recommendations on the type of arrangements and reward scheme designs to be established. The development of a CA uses the bottom-up approach and could also be used as a tool to assess whether the involved community has strong social or market norms.

An RPG is described as a device that could talk by itself, wherein facts that could hardly be communicated in an interview emerged implicitly and explicitly through the exercise (Vieira Pak and Castillo Brieva 2010).

A full econometric, social, psychological, and political analysis of what transpires in this type of RPG could fill many more pages, and would require further replications. We do not claim to fully understand the partial contrast between survey and RPG results, but suggest that a further joint exploration of the responses between villagers and intermediaries who have earned a minimum level of trust from the villagers can advance our understanding of what it takes to provide effective rewards for environmental services in a way that strengthens and supports existing social norms, rather than crowding them out.

van Noordwijk and Leimona (2010) described a "co-investment scheme" as a reward paradigm within the broad family of PES instruments that considers trust to be essential and that operates at a more abstract level of conditionality, which includes mutual accountability and commitment to sustainable development. In this scheme, the 
Table 7. Summary of the score sheets representing the yearly income of the villages vs. the target income to support the village population

\begin{tabular}{lcccccc}
\hline \hline & \multicolumn{5}{c}{ Income } \\
Villages & Year 0 & Year 1 & Year 2 & Year 3 & Year 4 & Year 5 \\
\hline Required/Target income & 75 & 75 & 75 & 90 & 90 & 90 \\
Lubuk Beringin & 75 & 75 & 85 & 85 & 90 & 58 \\
Desa Buat & 75 & 75 & 75 & 75 & 51 & 82 \\
Laman Panjang & 75 & 83 & 67 & 65 & 62 & 55 \\
\hline
\end{tabular}

conditionality is achieved when the buyers have full trust that the management plan (including local monitoring) set up by the community will enhance the provision of ecosystem services. Hence, landuse conflicts and their possible collateral damage to ecosystem services are reduced or avoided. Also, such types of PES schemes retain the reference to social exchange rather than financial transaction.

\section{CONCLUSION}

The results of the survey and RPG in this study suggest that the villagers have a strong conservation belief system that operates based on social norms. Thus, setting up a market-based scheme such as PES, which may introduce market norms, should be done carefully and based on an understanding of the local dynamics and conditions for free and prior informed consent. In conditions such as those found in Jambi, coinvestment schemes may be the appropriate starting level for any form of PES, as social norms are keys to success for environmental service enhancement.

The RPG as an experimental tool to explore social behavior in the context of rewards or payments for ecosystem services has proven to be effective in introducing PES concepts. Experience shows that there is the risk that community expectations could be unrealistic if the PES scheme is not well planned and cannot operate in a timely fashion, resulting in disappointment that could prevent real solutions (Leimona et al. 2008). Irrespective of whether a community is governed by social or market norms, complementing RPGs with survey questionnaires and interviews is crucial to reveal to outside stakeholders how the perceptions and behavior of the players are potentially modified in a context of social mobilization.

Responses to this article can be read online at: http://www.ecologyandsociety.org/voll6/iss3/art27/ responses/

\section{Acknowledgments:}

We would like to thank the DAAD and RUPES Program for financial assistance in conducting the $R P G$ and the survey, and ICRAF-RUPES Muarabungo staff, especially Ratna Akiefnawati, Jasnari, Rachman Pascha, and Suyitno, for helping to conduct the RPG. We acknowledge Delia Catacutan, Franz Gatzweiler, Joe Hill, David Huberman, Joshi Laxman, and Guenther Manske for their ideas, discussions of the concepts, and suggestions regarding earlier versions of this paper. We thank the anonymous reviewers for their helpful comments and suggestions, and Jess Fernandez and Mary $\mathrm{Ng}$ for proofreading the earlier drafts.

\section{LITERATURE CITED}

Akiefnawati, R., G. Villamor, F. Zulfikar, I. Budisetiawan, E. Mulyoutami, A. Ayat, and M. van Noordwijk. 2010. Stewardship agreement to reduce emissions from deforestation and degradation 
(REDD): Lubuk Beringin's hutan desa as the first village forest in Indonesia. International Forestry Review 10:349-360. http://dx.doi.org/10.1505/ifor. $\underline{12.4 .349}$

Ariely, D. 2008. Predictably irrational: the hidden forces that shape our decisions. HarperCollins, New York, New York, USA.

Barreteau, O., F. Bousquet, and J. M. Attonaty. 2001. Role-playing games for opening the black box of multi-agent systems: method and lessons of its application to Senegal River Valley irrigated systems. Journal of Articifial Societies and Social Simulations 4(2): 5. Available from: http://jasss.soc. surrey.ac.uk/4/2/5.html.

Barreteau, O., C. Le Page, and P. D' Aquino. 2003. Role-playing games, models and negotiation processes. Journal of Articifial Societies and Social Simulations 6(2): 10. Available from: http://jasss.so c.surrey.ac.uk/6/2/10.html

Bemelmans-Videc, M. L., R. C. Rist, and E. Vedung. 1998. Carrots, sticks, and sermons: policy instruments and their evaluation. Transaction Publishers, New Brunswick, New Jersey, USA.

Bennett, M. 2009. Eco-certification of jungle rubber: promise and realization. BioECON Conference, Venice, Italy.

Beukema, H., F. Danielsen, G. Vincent, S. Hardiwinoto, and J. van Andel. 2007. Plant and bird diversity in rubber agroforests in the lowlands of Sumatra, Indonesia. Agroforestry Systems 70:217242. http://dx.doi.org/10.1007/s10457-007-9037-x

Castella, J.-C., T. N. Trung, and S. Boissau. 2005. Participatory simulation of land-use changes in the northern mountains of Vietnam: the combined use of agent-based model, a role-playing game, and a geographic information system. Ecology and Society 10(1): 27. [online] URL: http://www.ecolog yandsociety.org/vol10/iss1/art27/

Child, M. F. 2009. The Thoreau ideal as unifying thread in the conservation movement. Conservation Biology 23:241-243. http://dx.doi.org/10.1111/j.15 23-1739.2009.01184.X

Clark, W. C., P. T. Tomich, M. van Noordwijk, D. Guston, D. Catacutan, N. M. Dickson, and E.
McNie. 2011. Boundary work for sustainable development: natural resource management at the Consultative Group on International Agricultural Research (CGIAR). Proceedings National Academy of Sciences, doi:10.1073/pnas.0900231108 http://d x.doi.org/10.1073/pnas.0900231108

D' Aquino, P., C. Le Page, F. Bousquet, and A. Bah. 2003. Using self-designed role-playing games and a multi-agent system to empower a local decisionmaking process for land use management: the selfcormas experiment in Senegal. Journal of Articifial Societies and Social Simulations 6(3): 5. [online] URL: http://jasss.soc.surrey.ac.uk/6/3/5.html

Dare, W., and O. Barreteau. 2003. A role-playing game in irrigated system negotiation: between play and reality. Journal of Articifial Societies and Social Simulations 6(3): 6. [online] URL: http://jasss.soc.s urrey.ac.uk/6/3/6.html

Ekadinata, E., M. Thoha Zulkarnain, and A. Widayati. 2010. Agroforestry area under threats: dynamics and trajectories of rubber agroforest in Bungo District, Jambi. World Agroforestry Centre, Bogor, Indonesia.

Engel, S., S. Pagiola, and S. Wunder. 2008. Designing payments for environmental services in theory and practice: an overview of the issues. Ecological Economics 65:663-674.

Etienne, M. 2003. SYLVOPAST: a multiple target role-playing game to assess negotiation processes in sylvopastoral management planning. Journal of Articifial Societies and Social Simulations 6(2). [online] URL: http://jasss.soc.surrey.ac.uk/6/2/5.html

Feintrenie, L., and P. Levang. 2009. Sumatra's rubber agroforests: advent, rise and fall of a sustainable cropping system. Small-scale Forestry 8:323-335. http://dx.doi.org/10.1007/s11842-009-9086-2

Gómez-Baggethun, E., R. de Groot, P. L. Lomas, and C. Montes. 2010. The history of ecosystem services in economic theory and practice: from early notions to markets and payment schemes. Ecological Economics 69:1209-1218. [online] URL: http://www.sciencedirect.com/science/article/ B6VDY-4XXM2HP-1/2/262d5bd14da586b14dfa2 e2590ac30fd 
Gouyon, A., H. de Foresta, and P. Levang. 1993. Does "jungle rubber" deserve its name? An analysis of rubber agroforesty system in Southeast Asia. Agroforestry Systems 22:181-200. http://dx.doi.org /10.1007/BF00705233

Griffith, D. M. 2000. Agroforestry: a refuge for tropical biodiversity. Conservation Biology 14:325-326. http://dx.doi.org/10.1046/j.1523-1739 .2000.99101.x

Gurung, T. R., F. Bousquet, and G. Trebuil. 2006. Companion modeling, conflict resolution, and institution building: sharing irrigation water in the Lingmuteychu Watershed, Bhutan. Ecology and Society 11(2): 36. [online] URL: http://www.ecolog yandsociety.org/vol11/iss $2 / \operatorname{art} 36 /$

Heyman, J., and D. Ariely. 2004. Effort for payment: a tale of two markets. Psychological Science 15:787-793. http://dx.doi.org/10.1111/j.09 56-7976.2004.00757.x

Jack, B. K., C. Kousky, and K. R. E. Sims. 2008. Designing payments for ecosystem services: lessons from previous experience with incentivebased mechanisms. Proceedings of the National Academy of Sciences 105:9465-9470. [online] URL: http://www.pnas.org/content/105/28/9465.abstract http://dx.doi.org/10.1073/pnas.0705503104

Jager, W., M. Janssen, H. J. M. de Vries, J. De Geef, and C. A. J. Vlek. 2002. Behaviour in common dilemmas: Homo economicus and Homo psychologicus in an ecological economic model. Ecological Economics 35:357-379.

Joshi, L., G. Wibawa, R. Akiefnawati, E. Mulyoutami, D. Wulandari, and E. Penot. 2006. Diversified rubber agroforestry for smallholder farmers-a better alternative to monoculture. In Proceedings, Rubber development in Lao PDR: exploring improved systems for smallholder rubber production. Vientiane, Lao PDR.

Joshi, L., G. Wibawa, H. Beukema, S. E. Williams, and M. van Noordwijk. 2003. Technological change and biodiversity in the rubber agroecosystem. Pages 133-157 in J. H. Vandermeer, editor. Tropical agroecosystems: new directions for research. CRC Press, Boca Raton, Florida, USA.

Kosoy, N., M. Martinez-Tuna, R. Muradian, and J. Martinez-Alier. 2007. Payments for environmental services in watersheds: insights from a comparative study of three cases in Central America. Ecological Economics 61:446-455.

Leimona, B., and L. Joshi. 2010. Eco-certified natural rubber from sustainable rubber agroforestry in Sumatra, Indonesia. World Agroforestry Centre, Bogor, Indonesia.

Leimona, B., L. Joshi, and M. van Noordwijk. 2009. Can rewards for environmental services benefit the poor? Lessons from Asia. Igitur. [online] URL: htt p://www.thecommonsjournal.org/index.php/ijc/article/ viewArticle/121

Leimona, B., M. van Noordwijk, G. Villamor, A. Fauzi, S. Upadhyaya, and Farida. 2008. Mobilization and local awareness of rights and opportunities for environmental services market. World Agroforestry Centre - ICRAF, Bogor, Indonesia.

Martinez-Alier, J. 2002. The environmentalism of the poor. Edward Elgar, Chelteham, UK.

Martini, E., R. Akiefnawati, L. Joshi, S. Dewi, E. Ekadinata, L. Feintrenie, and M. van Noordwijk. 2010. Rubber agroforest potentials as the interface between conservation and livelihoods in Bungo district, Jambi Province, Indonesia. ICRAF, Bogor, Indonesia. http://dx.doi.org/http://dx.doi.org/10.5716/ WP16881.PDF

Michon, G. 2005. Domesticating forests: how farmers manage forest resources. IRD, CIFOR and ICRAF, Bogor, Indonesia.

Miyamoto, M. 2006a. Forest conversion to rubber around Sumatran villages in Indonesia: comparing the impacts of road construction, transmigration projects and population. Forest Policy and Economics 9:1-12..

Miyamoto, M. 2006b. The relationship between forest conversion and inequality of land ownership, and the factors responsible for increasing the inequality in Sumatran rubber villages. Journal of the Japanese Forest Society 88:79-86

Miyamoto, M. 2007. Road construction and population effects on forest conversion in rubber villages in Sumatra, Indonesia. Pages 140-146 in Y. C. Dube and F. Schmithuesen, editors. Crosssectoral policy developments in forestry. CABI, Wallingford. UK. 
Murdiyarso, D., M. van Noordwijk, U. R. Wasrin, T. P. Tomich, and A. N. Gillison. 2002. Environmental benefits and sustainable land-use options in the Jambi transect, Sumatra. Journal of Vegetation Science 13:429-438. http://dx.doi.org/1 0.1111/j.1654-1103.2002.tb02067.x

Paavola, J., and W. N. Adger. 2005. Institutional ecological economics. Ecological Economics 53:353-368.

Peterson, M. J., D. M. Hall, M. Feldpausch-Parker, and T. R. Peterson. 2010. Obscuring ecosystem function with application of the ecosystem services concept. Conservation Biology 24:113-119. http:// dx.doi.org/10.1111/j.1523-1739.2009.01305.x

Rasnovi, S. 2006. Ecological regeneration of woody species in rubber agroforest system. Institut Pertanian Bogor, Bogor, Indonesia.

Schroth, G., G. A. B. da Fonseca, C. A. Harvey, C. Gascon, H. L. Vasconcelos, and A. M. N. Izac. 2004. Agroforestry and biodiversity conservation in tropical landscapes. Island Press, Washington, D. C., USA.

Soma, K. 2006. Natura economica in environmental valuation. Environmental Values 15:31-50.

Sterner, T. 2003. Policy instruments for environmental and natural resource management. Resources for the Future Press, Washington, D.C., USA.

Suyanto, S., R. K. Permana, N. Khususiyah, and L. Joshi. 2005. Land tenure, agroforestry adoption an reduction of fire hazard in a forest zone: a case study from Lampung, Sumatra. Agroforestry Systems 65:1-11. http://dx.doi.org/10.1007/s10457-004-1413-1

Tata, H. L., M. van Noordwijk, and M. Werger. 2008. Trees and regeneration in rubber agroforests and other forest-derived vegetation in Jambi (Sumatra, Indonesia). Journal of Forestry Research 5:1-20.

Tomich, T. P., D. E. Thomas, and M. van Noordwijk. 2004. Environmental services and land use change in Southeast Asia: from recognition to regulation or reward? Agriculture, Ecosystems and Environment 104:229-244. van Noordwijk, M., and B. Leimona. 2010. CES/ COS/CIS paradigms for compensation and rewards to enhance environmental services. World Agroforestry Centre, Bogor, Indonesia. http://dx.do i.org/10.5716/WP16555.PDF

van Noordwijk, M., B. Leimona, L. Emerton, T. P. Tomich, S. J. Velarde, M. Kallesoe, M. Sekher, and B. Swallow. 2007. Criteria and indicators for environmental service compensation and reward mechanism: realistic, voluntary, conditional and pro-poor. World Agroforestry Centre, Bogor, Indonesia. http://dx.doi.org/10.5716/WP14964.PDF

van Noordwijk, M., E. Mulyoutami, N. Sakuntaladewi, and F. Agus. 2008. Swiddens in transitions: shifter perceptions on shifting cultivators in Indonesia. ICRAF, Bogor, Indonesia.

van Noordwijk, M., T. P. Tomich, and B. Verbist. 2001. Negotiation support models for integrated natural resource management in tropical margins. Conservation Ecology 5(2): 21. [online] URL: http ://www.ecologyandsociety.org/vol5/iss2/art21/

Vatn, A. 2005. Institutions and the environment. Edward Elgar, Cheltenham, UK.

Vatn, A., and D. Bromley. 1994. Choices without prices without apologies. Journal of Environmental Economics and Management 26:129-148.

Vieira Pak, M., and D. Castillo Brieva. 2010. Designing and implementing a role-playing game: a tool to explain factors, decision making and landscape transformation. Environmental Modelling and Software 25:1322-1333.

Williams, S. E., M. van Noordwijk, E. Penot, J. R. Healey, F. L. Sinclair, and G. Wibawa. 2001. Onfarm evalution of the establishment of clonal rubber in multi-strata agroforests in Jambi, Indonesia. Agroforestry Systems 53:227-237. http://dx.doi.org /10.1023/A:1013336822923

Wunder, S. 2008. Payments for environmental services and the poor: concepts and preliminary evidence. Environment and Development Economics 13:279-297. 